\title{
Aerosol physical and optical properties in the Eastern Mediterranean Basin, Crete, from Aerosol Robotic Network data
}

\author{
A. Fotiadi ${ }^{1,2}$, N. Hatzianastassiou ${ }^{2,4}$, E. Drakakis ${ }^{2,3}$, C. Matsoukas $^{2,5}$, K. G. Pavlakis ${ }^{1,2,7}$, D. Hatzidimitriou ${ }^{1,2}$, \\ E. Gerasopoulos ${ }^{6,8}$, N. Mihalopoulos ${ }^{6}$, and I. Vardavas ${ }^{1,2}$ \\ ${ }^{1}$ Department of Physics, University of Crete, Crete, Greece \\ ${ }^{2}$ Foundation for Research and Technology-Hellas, Heraklion, Crete, Greece \\ ${ }^{3}$ Department of Electrical Engineering, Technological Educational Institute of Crete, Greece \\ ${ }^{4}$ Laboratory of Meteorology, Department of Physics, University of Ioannina, Greece \\ ${ }^{5}$ Department of Environment, University of the Aegean, Greece \\ ${ }^{6}$ Environmental Chemical Processes Laboratory, Department of Chemistry, University of Crete, Greece \\ ${ }^{7}$ Department of General Applied Science, Technological Educational Institute of Crete, Greece \\ ${ }^{8}$ Institute for Environmental Science and Sustainable Development, National Observatory of Athens, Athens, Greece
}

Received: 19 April 2006 - Published in Atmos. Chem. Phys. Discuss.: 10 August 2006

Revised: 2 November 2006 - Accepted: 23 November 2006 - Published: 4 December 2006

\begin{abstract}
In this study, we investigate the aerosol optical properties, namely aerosol extinction optical thickness (AOT), Angström parameter and size distribution over the Eastern Mediterranean Basin, using spectral measurements from the recently established FORTH (Foundation for Research and Technology-Hellas) AERONET station in Crete, for the two-year period 2003-2004. The location of the FORTH-AERONET station offers a unique opportunity to monitor aerosols from different sources. Maximum values of AOT are found primarily in spring, which together with small values of the Angström parameter indicate dust transported from African deserts, whereas the minimum values of AOT occur in winter. In autumn, large AOT values observed at near-infrared wavelengths arise also from dust transport. In summer, large AOT values at ultraviolet $(340 \mathrm{~nm})$ and visible wavelengths $(500 \mathrm{~nm})$, together with large values of the Angström parameter, are associated with transport of fine aerosols of urban/industrial and biomass burning origin. The Angström parameter values vary on a daily basis within the range $0.05-2.20$, and on a monthly basis within the range $0.68-1.9$. This behaviour, together with broad frequency distributions and back-trajectory analyses, indicates a great variety of aerosol types over the study region including dust, urban-industrial and biomass-burning pollution, and maritime, as well as mixed aerosol types. Large temporal variability is observed in AOT, Angström parameter, aerosol content and size. The fine and coarse aerosol modes persist
\end{abstract}

Correspondence to: N. Hatzianastassiou

(nhatzian@cc.uoi.gr) throughout the year, with the coarse mode dominant except in summer. The highest values of AOT are related primarily to southeasterly winds, associated with coarse aerosols, and to a less extent to northwesterly winds associated with fine aerosols. The results of this study show that the FORTH AERONET station in Crete is well suited for studying the transport and mixing of different types of aerosols from a variety of sources, especially those associated with major dust events from the Sahara.

\section{Introduction}

Aerosol particles affect the Earth's climate by influencing its radiation energy budget in two ways: i) directly (aerosol direct effect) by scattering and absorbing solar radiation, and ii) indirectly (aerosol indirect effect) by modifying the cloud microphysical, optical and radiative properties (cloud albedo and optical thickness, first indirect effect) or cloud amount, lifetime and precipitation efficiency (second indirect effect). Given the importance of aerosols, climate models now consider both the aerosol direct and indirect radiative forcings. However, despite significant progress in understanding aerosol effects on climate, there are still significant uncertainties related to their physical and optical properties, due to the large spatial-temporal variability and heterogeneity of aerosols, associated with their short atmospheric lifetime, and to the complex interactions between aerosols and clouds, in terms of their physical and chemical properties (IPCC, 2001; Haywood and Boucher, 2000; Lohmann

Published by Copernicus GmbH on behalf of the European Geosciences Union. 
and Feichter, 2005; Chen and Penner, 2005). In order to improve the situation, a worldwide effort has been undertaken since the early 1990s, to produce a global aerosol climatology by combining satellite-based observations (such as Total Ozone Mapping Spectrometer, TOMS; Moderate Resolution Imaging Spectro-Radiometer, MODIS; Multiangle Imaging Spectroradiometer, MISR; Polarization and Directionality of the Earth's Reflectance, POLDER) and measurements from ground-based monitoring networks (Aerosol Robotic Network, AERONET). These data sets are complemented with those of field campaigns (ground-based and airborne), for calibration and validation of satellite data.

A region that has received much interest with regard to aerosol effects is the climatically sensitive Mediterranean Basin, in particular its eastern part, where numerous experimental studies have taken place (Luria et al., 1996; Pinker et al., 1997; Mihalopoulos et al., 1997; Paronis et al., 1998; Papayiannis et al., 1998, 2005; Ichoku et al., 1999; Formenti et al., 2001a, b, 2002a, b; Andreae et al., 2002; Lelieveld et al., 2002; Kouvarakis et al., 2002; Zerefos et al., 2002; Gerasopoulos et al., 2003; Balis et al., 2004a, b). The Eastern Mediterranean is a crossroad where aerosols from different sources and mixtures of different kinds of particles converge, e.g. maritime aerosols from Mediterranean sea spray, seasonal biomass burning aerosols (Formenti et al., 2002a, b), anthropogenic aerosols transported by polluted air masses from urban and industrial areas (Lelieveld et al., 2002; Zerefos et al., 2000; Formenti, 2001b; Eisinger and Burrows, 1998), and mineral dust aerosols mainly from north African deserts, and to a lesser extent from the Middle East. Concentrations of trace gases and aerosols over the Mediterranean region are higher by factors 2 to 10 than those over the North Pacific Ocean, which is the least polluted environment at northern latitudes (Lelieveld et al., 2002). The significant aerosol loads in the Eastern Mediterranean Basin strongly influence the radiation budget, and hence the climate of the region, especially during summer (e.g. Lelieveld et al., 2002; Hatzianastassiou et al., 2004).

In order to improve our scientific knowledge of the climatic role of aerosols for the Mediterranean Basin, and the accuracy of radiation budget model results, more and better data on aerosol properties and loads are required. In this regard, site-specific ground-based aerosol data, from the global network AERONET, are provided as continuous time series with a very high temporal resolution.

The globally distributed AERONET (Holben et al., 1998, 2001), which is an automated robotic Sun- and sky scanning measurement program, was established in the early 1990s and is growing rapidly in the number of stations. Since January 2003, a new AERONET station (FORTH), was installed in Crete, additional to others in the Eastern Mediterranean (Sede Boker, Ness Ziona, Dead Sea, Erdemli). The location of the FORTH-AERONET station is unique, located in a relatively isolated island in the central part of the Eastern Mediterranean Basin (Fig. 1).
In this work, aerosol measurements from the FORTHAERONET station in Crete are analysed, to characterise aerosol properties over the Eastern Mediterranean Basin. The aerosol data include aerosol optical thickness (AOT) at 340,500, 870, and $1020 \mathrm{~nm}$, Angström parameter, and aerosol volume-size distribution, which cover the complete 2-year period 2003-2004, allowing the annual aerosol cycle to be studied.

A brief description of the data and the retrieval procedure is given in Sect. 2. In Sect. 3, the seasonal variation of aerosol optical properties is discussed, with emphasis on the transport of dust aerosols from Africa. In addition, the relationship between the Angström parameter and the aerosol optical thickness, and the features of the aerosol volume-size distribution are also examined. Finally, we investigate the relationship between aerosol properties, air masses, and wind direction and speed.

\section{The data used}

The aerosol data used in this work were derived from measurements carried out by the FORTH-CRETE AERONET station, which is located on the northern coast of Crete $\left(35^{\circ} 19^{\prime} 58^{\prime \prime} \mathrm{N}, 25^{\circ} 16^{\prime} 55^{\prime \prime} \mathrm{E}, 20 \mathrm{~m}\right.$ altitude, Fig. 1). The station is located $15 \mathrm{~km}$ east from Heraklion, which is the largest city in Crete with about 200000 inhabitants. The measured aerosol data cover the period January 2003 to December 2004 inclusive. The measurements were made with the CIMEL sunphotometer (CE-318) an automatic sun-sky scanning spectral radiometer. The instrumentation is set up on the roof of the building of National Center for Marine Research in Crete, which is $20 \mathrm{~m}$ high and is found $100 \mathrm{~m}$ from the coast. The instrumentation, data acquisition, retrieval algorithms and calibration procedure conform to the standards of the AERONET global network, and are described in detail, along with the uncertainty of final released products, by Holben et al. (1998), Dubovik and King (2000), Dubovik et al. (1998, 2000, 2002) and Kaufman et al. (2002). In brief, the solar extinction measurements taken every $15 \mathrm{~min}$ within the spectral range 340-1020 nm (Holben et al., 2001), are used to compute AOT at 340, 380, 440, 500, 675, 870, 970 and $1020 \mathrm{~nm}$. Sky radiance almucantar measurements in conjunction with direct Sun measurements of AOT at 441, 673,873 and $1022 \mathrm{~nm}$ are used to retrieve columnar size distributions (from 0.05 to $15 \mu \mathrm{m}$ ), single scattering albedo, and refractive indices of the aerosols (Dubovik and King, 2000). The Angstrom parameter is computed from AOT at 440 and $870 \mathrm{~nm}$. The overall uncertainty in AOT data, under cloud-free conditions, is \pm 0.01 for $\lambda>440 \mathrm{~nm}$, and \pm 0.02 for shorter wavelengths. The error in aerosol volume size distribution is estimated to be $\sim 15-25 \%$ for radii between 0.1 and $7 \mu \mathrm{m}$ (see Dubovik et al., 2000, 2002a, b). In this study, level 2.0 AERONET data are used; specifically, we analyse daily mean values of AOT, Angström parameter and volume 
size distribution of aerosol particles. For AOT, we have chosen to use spectral values at $340,500,870$ and $1020 \mathrm{~nm}$ to cover the solar spectrum for which aerosol properties are most relevant.

Analytical air-mass back trajectories of 4-days obtained with the Hybrid Single-Particle Lagrangian Integrated Trajectory Model (HYSPLIT), are also used in this study to identify the pathway of air-masses over Crete. The back trajectories are computed for 3 distinct arrival levels, namely 500,1500 and $3000 \mathrm{~m}$ at 12:00 UTC, on a day-by-day basis.

Collocated meteorological observations are made by an automatic meteorological station operating at the AERONET FORTH-CRETE site. Air-temperature, wind speed and direction and relative humidity are routinely recorded as 15 min averages. The total (direct and diffuse) shortwave and longwave solar radiation measurements are made by the Kipp \& Zonen CG4 and CM11 radiometers, respectively. The meteorological data are available since 20 June 2003, when the meteorological station was set up, i.e. 6 months later than the start of operation of the AERONET station.

\section{Results and discussion}

\subsection{Seasonal variability of aerosol optical properties}

The time series of monthly mean AOT values at four wavelengths $(340,500,870$ and $1020 \mathrm{~nm})$ as well as that of monthly mean Angström parameter, $\alpha_{440-870}$ (evaluated at 440 and $870 \mathrm{~nm}$ ), for the FORTH-AERONET station in Crete are given in Fig. 2, over the 2-year period 2003-2004. Figure 3 shows the seasonal variation of AOT and $\alpha_{440-870}$. The monthly mean values were computed from corresponding daily means (not shown here). The annual variation of AOT in the ultraviolet and visible has maximum values in spring (March-May), late summer and autumn (August and October) and minimum values in winter and early summer (June). At the near-infrared wavelengths of 870 and $1020 \mathrm{~nm}$, there are clear AOT maxima in spring, but also in autumn (not so strong at 340 and $500 \mathrm{~nm}$ ) and minimum values in winter. At 340 and $500 \mathrm{~nm}$ the AOT exhibits a plateau of high values in summer.

The AOT values at 340, 500, 870 and $1020 \mathrm{~nm}$ (Fig. 3) indicate a significant spectral dependence of aerosol optical thickness, with decreasing annual mean values from $0.34 \pm 0.14$ at $340 \mathrm{~nm}$ down to $0.11 \pm 0.09$ at $1020 \mathrm{~nm}$, implying an AOT reduction of $68 \%$ from near-UV to near-IR wavelengths. Comparison between Figs. 2a, b, c and d, reveals also a spectral difference in the seasonal cycle of AOT. Apart from the spring maximum and winter minimum, there are relatively high autumn and low summer AOT values pronounced at 870 and $1020 \mathrm{~nm}$, in contrast to near-UV and visible wavelengths. Note that the annual variation of AOT at UV-visible wavelengths is larger than in the IR (see Fig. 3). The spectral differences in the annual cycle of AOT shown

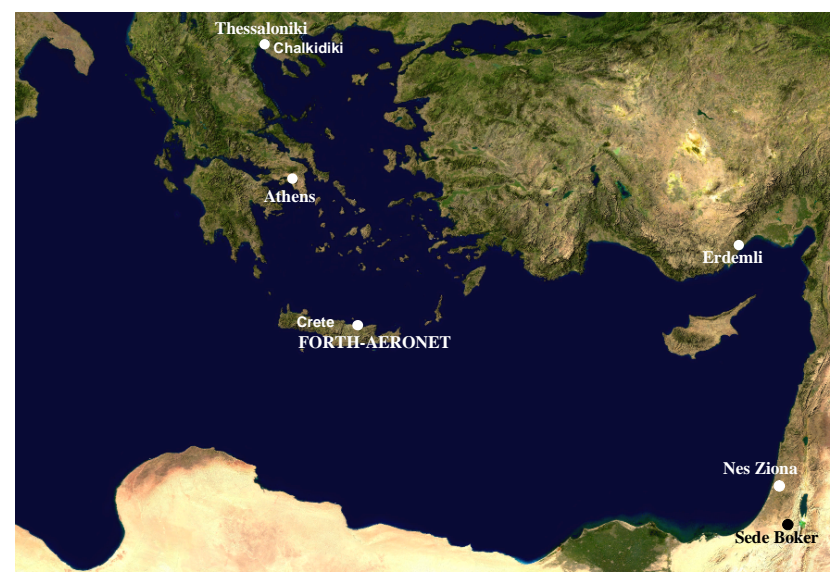

Fig. 1. The Eastern Mediterranean basin and the site of the FORTH_CRETE AERONET station on the island of Crete.

in Figs. 2 and 3 indicate the presence of aerosols of different size distributions and chemical composition throughout the year over Crete. Indeed, the aerosol population over Crete is heterogeneous, and based on field campaigns, it has been found to be composed of mineral dust, marine biogenic particles and anthropogenic aerosols at different layers (Lelieveld et al., 2002; Kouvarakis et al., 2002; Bardouki et al., 2003; Sciare et al., 2003). The standard deviations of AOT (Figs. 2a, b, c, d) are found to be largest during spring, i.e. when AOT is maximum, indicating strong day-to-day variability in aerosol load over Crete associated with frequent dust events. Large standard deviations of AOT could be also related to variability in wet deposition processes, associated with local meteorological conditions. Note also that there are fewer winter daily values from which monthly means can be computed because of cloud screening, in contrast to the clearsky conditions during summer. On a daily basis, peak values of $\mathrm{AOT}_{500}$, as high as 0.91 in March 2004, 0.5 in September 2003, and 0.46 in May 2004 are found, with even larger values at $340 \mathrm{~nm}$, and smaller ones at $1020 \mathrm{~nm}$.

The high spring and autumn AOT values are associated with strong dust episodes taking place in these seasons (Dayan et al., 1991; Marticorena and Bergametti, 1996; Moulin et al., 1998; Karyampudi et al., 1999; Prospero et al., 2002; Israelevich et al., 2002, 2003; Kubilay et al., 1995, 2003; Kalivitis et al., 2006) when dust particles are transported from North African deserts. This is indicated by lower values of the Angström parameter during spring and autumn (see Fig. 2e). During spring, strong aerosol activity takes place in the eastern Mediterranean, where dust is transported by thermal lows (Sharav cyclones) created over the North Africa deserts which then move along the African coast from west to east (Alpert and Ziv, 1989; Dayan et al., 1991; Moulin et al., 1998; Karyampudi et al., 1999; Barkan et al., 2005). Israelevich et al. (2002) have shown that during spring and summer desert dust is always present in the 

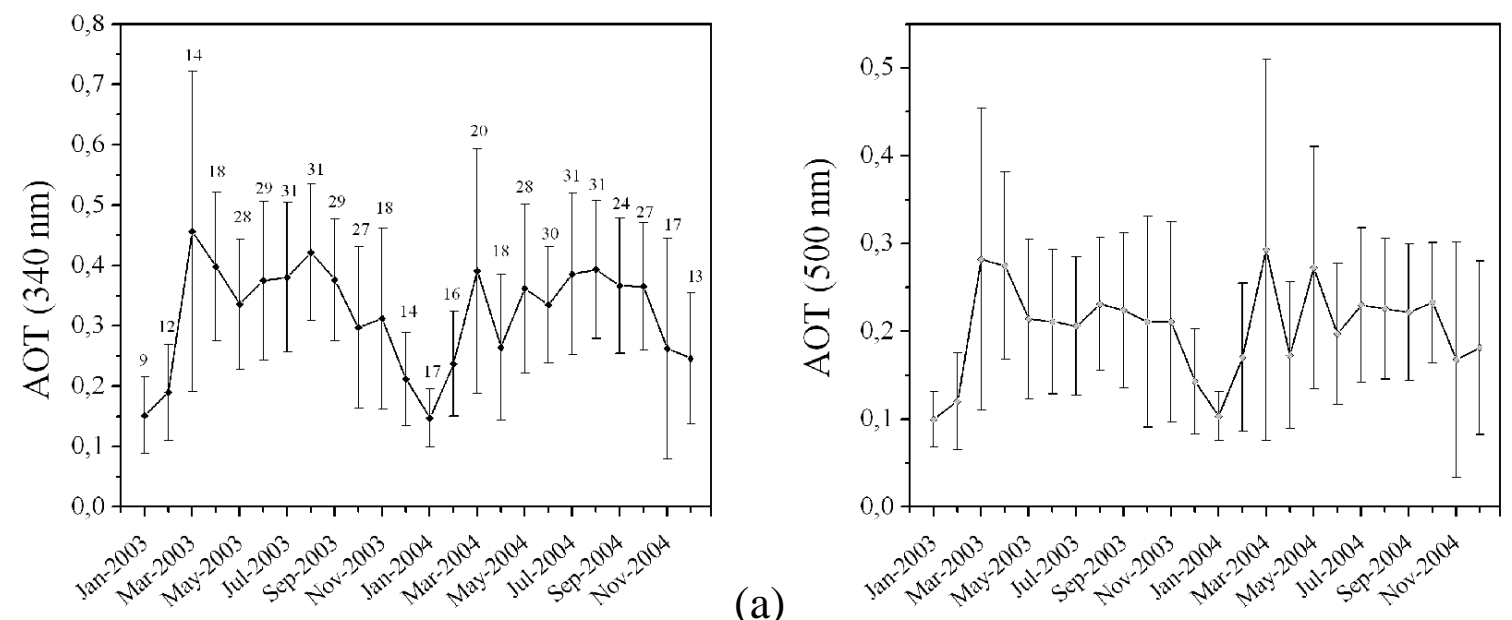

(b)

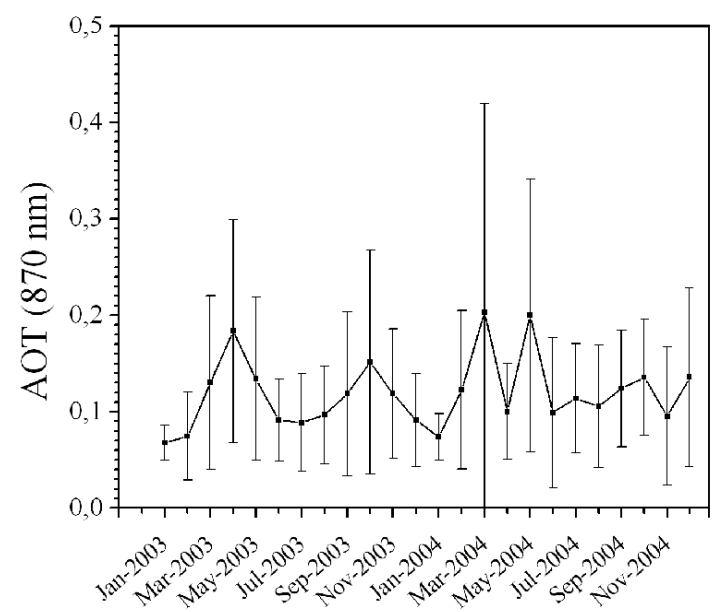

(c)

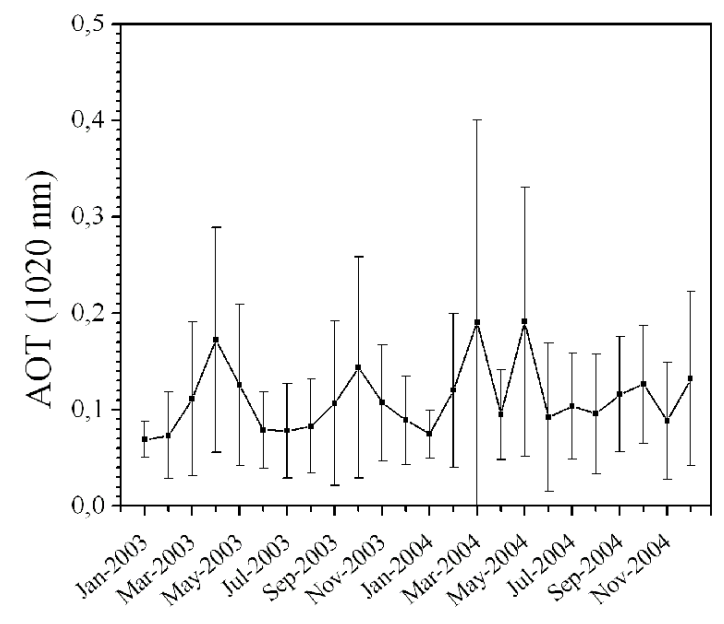

(d)

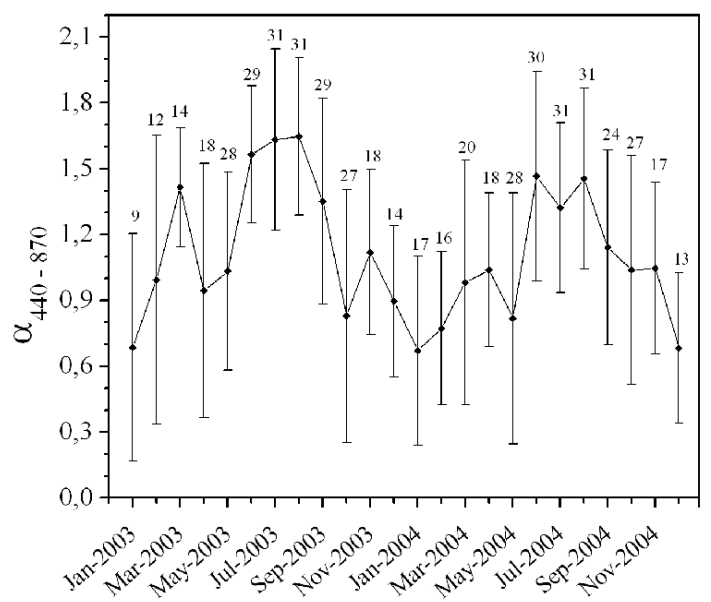

(e)

Fig. 2. Time-series of computed monthly mean aerosol optical thickness (AOT) at (a) $340 \mathrm{~nm}$, (b) $500 \mathrm{~nm}$, (c) $870 \mathrm{~nm}$, and (d) $1020 \mathrm{~nm}$, and of the Angström parameter, $\alpha_{440-870}$, derived from AOT measurements at 440 and $870 \mathrm{~nm}$ (e), for the two-year period 2003-2004 at the FORTH-AERONET station in Crete. Standard deviation $( \pm \sigma)$ values are also given (vertical bars) along with the number of days over which the monthly means are computed. 
region's atmosphere. Dust is transported over the Mediterranean basin whenever meteorological conditions are appropriate and most time dust intrusions occur in the form of "storms". Recently, Kalivitis et al. (2006), using multiyear $\mathrm{PM}_{10}$ measurements in conjunction with TOMS and AERONET aerosol data, have shown that aerosols arrive over Crete, either simultaneously in the lower-free troposphere and inside the boundary layer, or initially into the free troposphere with the heavier particles gradually being scavenged inside the boundary layer. Both pathways contribute almost equally to the dust transport over Crete in spring.

We have performed a systematic 4-day back-trajectory analysis which revealed that in addition to advection of dust from North African deserts, mineral dust particles can be advected to Crete from the Middle-East and Arabian Peninsula, though less frequently. In contrast, there are local minimum AOT values in June, when cyclones that develop in west Sahara are blocked by high-pressure systems over Libya, and thus cannot reach the eastern Mediterranean, travelling therefore northward and transporting dust to the central and western Mediterranean (Moulin et al., 1998; Israelevich et al., 2002). This underlines the importance of synoptic systems to aerosol loads in the Eastern Mediterranean Basin.

The maximum AOT values in spring and autumn (Fig. 2) can also be associated with maritime aerosols, produced by sea spray, mixed with dust aerosols. Several studies have shown that unique aerosol types never occur in the atmosphere, but aerosol populations are rather mixtures of various aerosol types (Pruppacher and Klett, 1997); this was shown to be valid for Crete (Lelieveld et al., 2002). Nevertheless, the contribution of sea-salt aerosols should be more important in autumn as indicated by smaller values of TOMS aerosol index (see Kalivitis et al., 2006), with respect to spring.

The plateau of high AOT values in summer at the smaller wavelengths is probably related to the stable atmospheric conditions during this period in the Mediterranean, which favour the accumulation of fine aerosol particles advected by long-range transport processes mainly from the north. Note that, during this period the aerosol wet removal is practically absent over the southeastern Mediterranean (Bartzokas et al., 2003). The presence of absorbing anthropogenic fine-mode aerosols in summer over Crete, is supported by corresponding mean monthly Angström parameter $\left(\alpha_{440-870}\right)$ values of $1.6 \pm 0.4$ (Fig. 2e), and by large (2-3) values of the TOMS aerosol index (cf. Kalivitis et al., 2006). The presence of fine urban-industrial aerosols, either from local sources or transported from continental polluted air masses, has been identified by performing back-trajectory and meteorological analyses. These analyses revealed that such cases are associated with northern wind directions, with air masses originating primarily from central Europe and the Balkan peninsula, carrying pollution from areas such as Athens, Eastern Europe, and western Turkey, and secondarily from Western and North-Western Europe. During summer, the broader

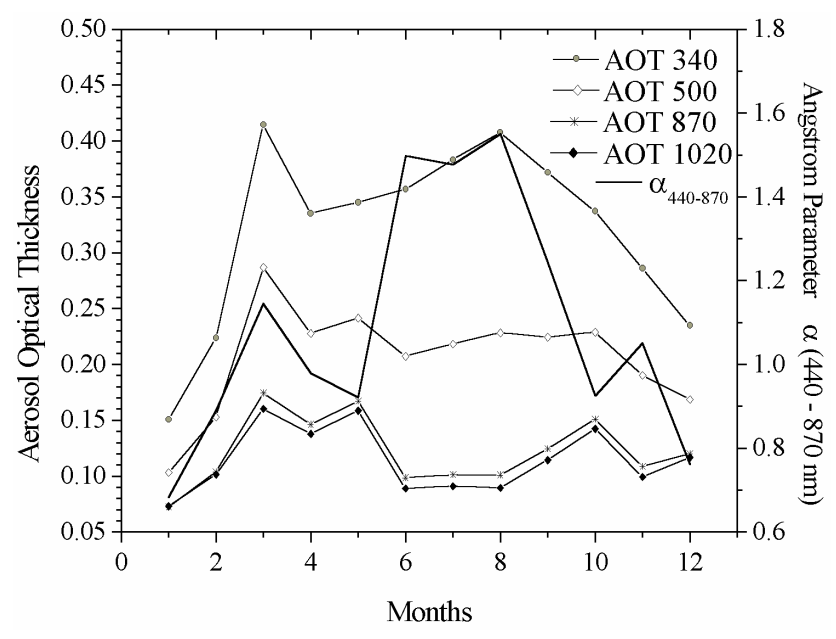

Fig. 3. Intra-annual variation of aerosol optical thickness (AOT) at $340 \mathrm{~nm}, 500 \mathrm{~nm}, 870 \mathrm{~nm}$, and $1020 \mathrm{~nm}$, and of the Angström parameter, $\alpha_{440-870}$, derived from AOT at 440 and $870 \mathrm{~nm}$, at the FORTH-AERONET station in Crete.

Greek region and generally the Eastern Mediterranean Basin, are under the influence of two pressure systems: the quasipermanent Azores anticyclone and the Pakistan thermal lowpressure system, which extends through to the Middle-East up to the South Anatolian plateau (Metaxas and Bartzokas, 1994; Palutikof et al., 1996; Katsoulis et al., 1998). Thus, a strong pressure-gradient is created over the Aegean Sea, resulting in northerly "etesian" winds that carry to Crete anthropogenic aerosols from Central and Eastern Europe, the Balkans, and the city of Athens.

The low monthly mean AOT values during winter, down to 0.15 for $\mathrm{AOT}_{340}$ and 0.1 at other wavelengths, together with $\alpha_{440-870}$ values mostly within the range $0.7-1$, indicate near background conditions dominated by marine aerosols. Although this is based on relatively few AERONET data, it is in agreement with measurements performed during winter (Bardouki et al., 2003) that indicate a significant contribution from sea-salt compared to dust. Time-series of AOT and $\alpha_{440-870}$ together with back-trajectory analyses have shown that dust outbreaks can also take place in winter, but they are rather rare. This is normal given the less favourable conditions for dust-transport to occur. Indeed, the synoptic pattern over the region during winter is characterised by; (1) the Siberian anticyclone causing polar continental air to flow from eastern Europe, (2) an anticyclone over middle and eastern Europe, and (3) the low-pressure systems in the central Mediterranean, moving usually from west to east. These regimes are rather favourable to the transport of fine anthropogenic aerosols, resulting in smaller values of AOT during this season. In spite of this, Kalivitis et al. (2006) have shown that intense vertically extended dust transport events can also take place in winter. The small winter AOT values are also consistent with aerosol mixing processes, involving 
low-concentration maritime aerosols from sea-spray (whose production increases in winter due to strong winds), as well as efficient wet-removal aerosol processes due to cloudy conditions and precipitation.

Note that there is a year-to-year variability in aerosol properties. Thus, there is a slightly larger AOT variability and magnitudes in summer 2004, associated with more daily peaks in AOT (not shown here), which is probably due to the more frequent dust transport in summer 2004 than 2003, also depicted by the lower values of $\alpha_{440-870}$ in the summer of 2004. This is also evident in surface $\mathrm{PM}_{10}$ measurements in Crete (see Gerasopoulos et al., 2006). Note also that summer mean values of $\mathrm{AOT}_{340}$ and $\alpha_{440-870}$ are slightly lower in 2004 (0.37 and 1.41, respectively) than 2003 (0.39 and 1.62 , respectively). This could be also due to the presence of more fine aerosol particles in summer 2003 than 2004, which can be related to the fact that the summer of 2003 was the hottest in Europe since 1500 (Luterbacher et al., 2004), with a persistent high-pressure system established over western Europe during July and August 2003, resulting in extremely hot and dry weather conditions. Such conditions favoured the development of numerous huge forest fires in Portugal, Southern France, Italy and the Balkans, as illustrated well by satellite images (http://visibleearth.nasa.gov, http: //landqa2.nascom.nasa.gov/), producing strong emissions of fine-mode aerosols that accumulated in the atmosphere under stable conditions. Therefore, the prevailing synoptic conditions and the flow from the north over Crete advected a significant amount of anthropogenic and biomass burning aerosols. It has been shown (e.g. Gerasopoulos et al., 2005) that the 2003 heat wave influenced pollution.

The seasonality and magnitude of AOT in Crete are in general agreement with those reported for Erdemli (Kubilay et al., 2003) located on the southern Turkish coast, and Sede Boker (Holben et al., 2001; Israellevich et al., 2003) in Israel. However, small differences are found as well. For the same period (2003-2004), Erdemli-AERONET data show larger AOT values at near-IR wavelengths during late summer than in Crete. The Sede Boker AERONET site (see Fig. 1), is characterised by more intense spring AOT maximum values and slightly smaller values in summer. On the other hand, a similarity exists between the FORTH and Nes Ziona AERONET sites. In addition, a different seasonal variation has been reported by Gerasopoulos et al. (2003) for two sites in Northern Greece, one rural (Chalkidiki) and the other urban (Thessaloniki). A distinct annual cycle of $\mathrm{AOT}_{500}$ has been reported for the former rural site, with summer maximum and winter minimum values, whereas no clear seasonal cycle was found at the latter urban site, due to the permanent local pollution sources. The differences between these two sites and the FORTH-AERONET site in Crete can be explained by their different locations. Crete is an island in the central part of the Eastern Mediterranean Basin, in relatively close proximity to North Africa, while Northern Greece is far enough from dust sources, allowing the deposition pro- cesses to be more effective and the aerosol population to be depleted. Thus, Papayannis et al. (2005) in the framework of the project EARLINET (A European Aerosol Research Lidar Network) reported more than 50 dust events in Athens versus 17 over Thessaloniki during the period 2000-2002. Nevertheless, there are also similarities between our findings and the results given by Gerasopoulos et al. (2003), comprising large AOT Angström parameter values in summer (August), which are mainly linked to fine aerosol particles transported from Eastern Europe. Despite this, the slightly larger AOT in Northern Greece, given by Gerasopoulos et al. (2003) and Balis et al. (2003), than in Crete during summer are due to the fact that Northern Greece is closer to pollution sources in Central and Eastern Europe than is Crete. Moreover, the FORTH-AERONET station is located in a maritime environment and maritime aerosol concentrations are generally smaller than continental ones (Jaenicke, 1993).

3.2 Frequency distributions of aerosol optical thickness and Angström parameter

The distribution of percent frequency of occurrence of daily averages of spectral AOT values and Angström parameter $\left(\alpha_{440-870)}\right)$ for each season are shown in Fig. 4.

\subsubsection{Aerosol optical thickness}

The histograms of $\mathrm{AOT}_{340}$ (Figs. 4i) are quite broad with values occurring even at $\sim 1.2$ in spring. A large fraction (80$90 \%$ ) of the daily averaged $\mathrm{AOT}_{340}$ values are almost equally distributed within the range $0.1-0.5$; these cases correspond either to strong dust outbreaks or to heavy pollution events. The winter season presents the narrowest $\mathrm{AOT}_{340}$ frequency distribution (Fig. $4 \mathrm{i}-\mathrm{a}$ ) with a maximum of about $30 \%$ of total values at 0.125 corresponding to background conditions. Thus, $70 \%$ of total $\mathrm{AOT}_{340}$ daily observations have values between 0.1 and 0.25 . In spring the frequency distribution broadens out to larger near-infrared optical depths (Fig. 4ib) mainly due to the frequent occurrence of dust episodes in this season (see Sect. 3.1). Therefore, the maximum probability of $\mathrm{AOT}_{340}$ shifts towards greater values (0.375). A significant portion of spring daily values $(21 \%)$ have $\mathrm{AOT}_{340}>0.45$, and $7 \%$ has $\mathrm{AOT}_{340}>0.6$. The frequency of occurrence of $\mathrm{AOT}_{340}$ in summer (Fig. 4i-c) exhibits a broad peak within the range of values $0.25-0.45$, yielding $62 \%$ of total observations in this season, whereas another $25 \%$ have $\mathrm{AOT}_{340}$ values up to 0.6 . These values indicate the predominance of continental anthropogenic aerosols. A portion of $20 \%$ of total daily values with $\mathrm{AOT}_{340} \geq 0.525$ correspond to fine particles, especially smoke aerosols from biomass burning. The autumn frequency distribution is broader, showing $\mathrm{AOT}_{340}$ peaks near $0.2-0.3$ and $0.35-0.45$.

The frequency distributions of $\mathrm{AOT}_{500}$ (Fig. 4ii) are broad, having values up to $\sim 0.9$. The maximum frequencies of occurrence of $\mathrm{AOT}_{500}(63-80 \%)$ are centered around $0.1-0.3$, 


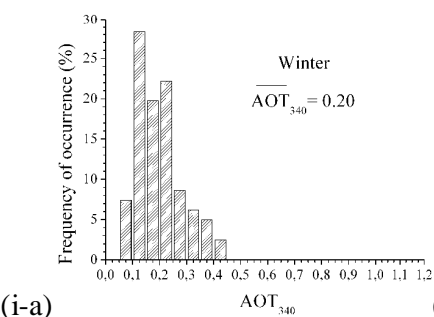

(i-a)

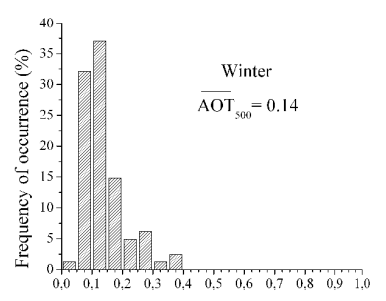

(ii-a)

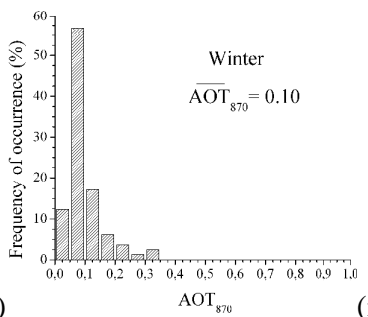

(iii-a)

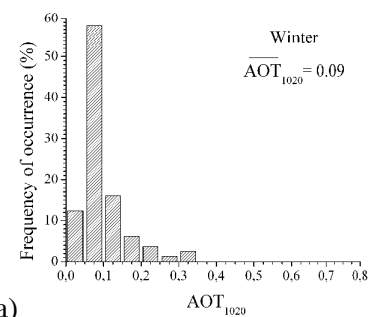

(iv-a)

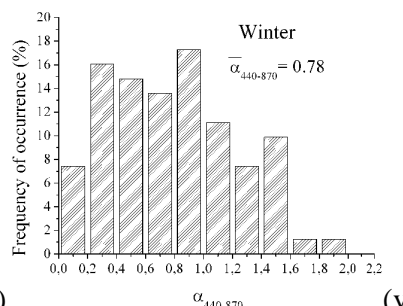

(v-a)

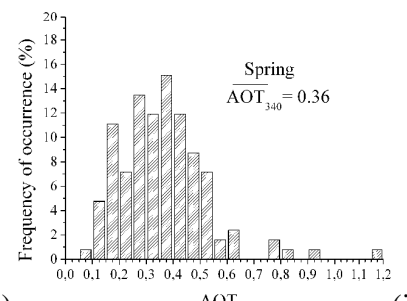

(i-b)

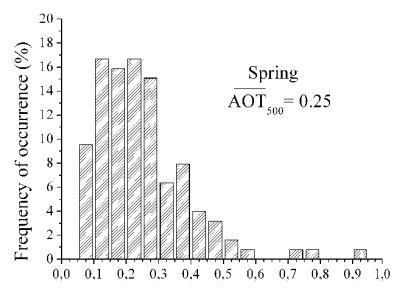

(ii-b)

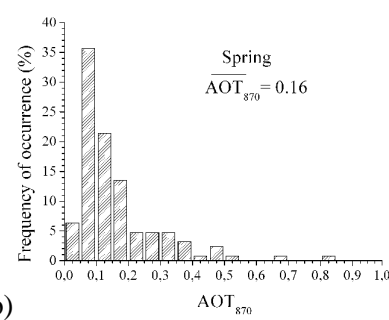

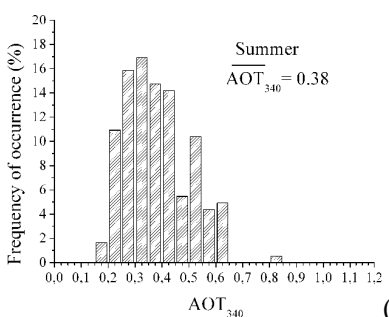

(i-c)

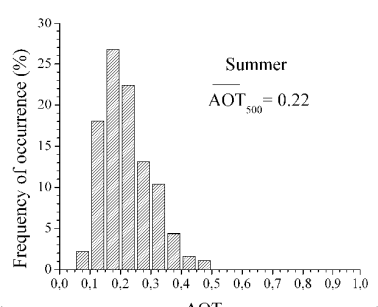

(ii-c)

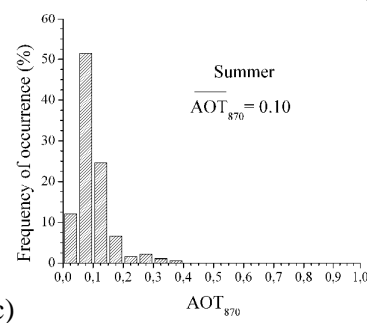

(i-d)

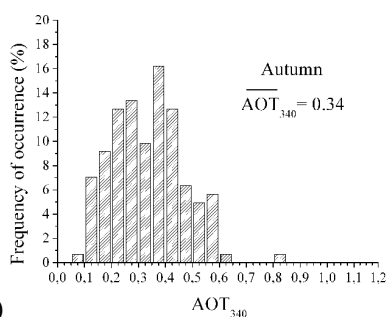

(ii-d)

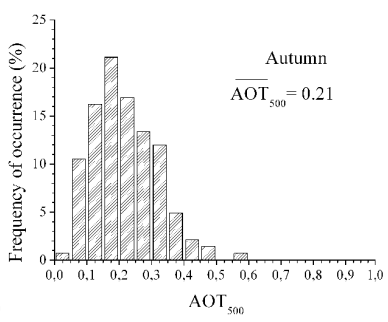

(iii-d)

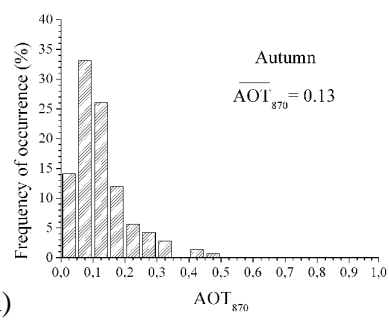

Fig. 4. Seasonal frequency of occurrence (\%) of daily mean aerosol optical thickness (AOT) at (i) $340 \mathrm{~nm}$, (ii) $500 \mathrm{~nm}$, (iii) $870 \mathrm{~nm}$ and (iv) $1020 \mathrm{~nm}$, and (v) of Angström parameter $\left(\alpha_{440-870}\right)$ measured at the FORTH-AERONET station in Crete, for the 2-year period 20032004 during (a) winter (December-January-February), (b) spring (March-April-May), (c) summer (June-July-August) and (d) autumn (September-October-November). Seasonal mean values are also given.

with steadily decreasing values at larger optical depths, quite similar to distributions of $\mathrm{AOT}_{340}$ for each season. The winter distribution is narrower compared to the others, whereas the spring distribution is the broadest one. Note that in spring about $25 \%$ of total $\mathrm{AOT}_{500}$ data have values beyond the range $0.1-0.3$.
The frequency of occurrence of AOT at near-IR wavelengths (870 and $1020 \mathrm{~nm}$, Figs. 4iii and 4iv, respectively) is almost identical. They are both narrower than frequency distributions at near-UV and visible wavelengths. The maximum frequencies $(35-50 \%)$ are found around 0.075 . In spring, about $25 \%$ of total days have $\mathrm{AOT}_{1020}>0.2$, and are 
characterised by dust transport. This is also the case in autumn, though to a smaller extent, with about $10 \%$ of total days with $\mathrm{AOT}_{1020}>0.2$.

\subsubsection{Angström parameter}

The frequency distribution of occurrence of the daily mean Angström parameter $\left(\alpha_{440-870}\right)$ values (Fig. $\left.4 \mathrm{v}\right)$ is broad, covering the range $0.05-2.15$, owing to the great variety of aerosol types (such as urban/industrial, dust, maritime or mixtures) and sizes in the atmosphere over Crete, which in turn is due to the location of the FORTH-AERONET monitoring site in the central part of the Eastern Mediterranean Basin, surrounded by many different emission sources. Note that values of $\alpha_{440-870}$ do not exceed 2.2 (only 6\% of $\alpha_{440-870}$ values are $>2.0$ in summer) in contrast to continental polluted sites (Holben et al., 2001). This is due to the relatively remote marine environment of the FORTHAERONET station, far from polluted areas. The histograms of $\alpha_{440-870}$ tend to be bimodal. Seasonal differences are revealed from the diagrams of Fig. $4 \mathrm{v}$. Thus, the atmosphere over Crete has quite small $\alpha_{440-870}$ values in winter (Fig. $4 \mathrm{v}-$ a), with $70 \%$ of the cases with $\alpha_{440-870}<1.0$. In combination with the small winter AOT values (Figs. 4i, ii, iii, iv), this implies that aerosol populations in winter are dominated by low-concentration sea-salt aerosols, as stated in Sect. 3.1. In contrast, the frequency distribution of $\alpha_{440-870}$ in summer is skewed towards large $\alpha_{440-870}$ values, with $88 \%$ of the cases having $\alpha_{440-870}>1.0$. Thus, the aerosol populations are dominated by fine mode particles during summer. During the transient seasons the situation is totally different. In spring, the frequency distribution of $\alpha_{440-870}$ is rather uniform with $\alpha_{440-870}$ values equally distributed in size bins from 0 to 1.7 . More than $25 \%$ of the cases have $\alpha_{440-870}<0.5$, associated with dust particles. In autumn, the probability distribution of $\alpha_{440-870}$ has a clearer bimodal structure with two distinct modes near 0.5 and 1.5 related with dust/maritime coarse particles, and continental urban/industrial-fine aerosols, respectively.

\subsection{Aerosol optical thickness, Angström parameter and} wind direction

The scatterplot of Angström parameter $\alpha_{440-870}$ versus $\mathrm{AOT}_{870}$ is shown in Fig. 5 for each season. Such correlations between AOT and Angström parameter, complemented by traced back trajectories of air masses, and prevailing seasonal winds, allow inferences to be made on the type of aerosols. At a first glance, there seem not to be clearly separated groups of points in the scatterplots, as in corresponding plots for other sites, indicating the presence of mixed aerosol populations over Crete. However, when one looks in more detail, different modes of aerosols can be identified in Fig. 5. Distinct areas at the bottom righthand side of the plots with small values of $\alpha_{440-870}(<0.5-$
0.6) and large values of $\mathrm{AOT}_{870}(>0.20-0.25)$ are related to coarse particles, associated with dust outbreaks in North African deserts mainly during spring but also in late summer and autumn (27, 7, and 15 cases, respectively). In contrast, few cases (6) are found in winter. However, there are cases (7) of coarse particles $\left(\alpha_{440-870}<0.5\right)$, but with smaller loads (AOT $870 \sim 0.10-0.15$ ) corresponding either to transported dust or maritime particles. Distinct areas at the top of the plots with $\alpha_{440-870}>1.5-1.6$ and $\mathrm{AOT}_{870}>0.05-0.1$ indicate the predominance of fine aerosols of anthropogenic and biomass-burning origin. This is the case mainly in summer (91 cases), and much less in spring and fall (22 and 29 cases, respectively). Note that there is a wide range of $\alpha_{440-870}$ values $(\sim 0.10-2.0)$ for $\mathrm{AOT}_{870}<0.2$, associated with background aerosol conditions, involving various types of particles namely background sulfate maritime aerosols, mineral dust, soot, and other continental natural or anthropogenic particles. This is supported by back-trajectories. Our analysis has shown that during dust events, the air masses either originated from the Atlantic Ocean that travelled over western Mediterranean and North Africa to reach Crete, or originated from North Africa deserts and travelled across central Mediterranean or the Libyan Sea before arriving over Crete. Both pathways suggest active mixing processes of aerosols. Mixed aerosol types are also indicated by points with values of $\mathrm{AOT}_{870}>0.15$ and $\alpha_{440-870}$ between 0.5 and 1.5. Back-trajectory analysis for these cases revealed that they usually correspond to mixtures of dust with urban/industrial aerosols, transported either from Western Europe (Atlantic Ocean, Spain, France, Italy) or from Central and Eastern Europe. In addition, there are cases for which air masses come from the NW or NE, and pass over Athens, thus advecting urban pollution to Crete.

The aerosol optical thickness and Angström parameter $\left(\alpha_{440-870)}\right)$ are strongly depended on the prevailing wind conditions at the FORTH-AERONET station in Crete. Figure 6 shows rose diagrams of $\mathrm{AOT}_{340}, \mathrm{AOT}_{870}$ and Angström parameter, as functions of wind direction, on a daily basis, over the study period. The corresponding diagrams for $\mathrm{AOT}_{500}$ and $\mathrm{AOT}_{1020}$ are very similar to the ones of $\mathrm{AOT}_{340}$ and $\mathrm{AOT}_{870}$, respectively. The maximum values of AOT occur for wind directions from easterly to southerly $\left(90^{\circ}-180^{\circ}\right)$ and from the northwest. Nevertheless, note that NW wind directions are absent from the $\mathrm{AOT}_{870}$ diagram (Fig. 6b), but they exist for $\mathrm{AOT}_{340}$ (Fig. 6a). This indicates that NW winds are associated with maximum loads of fine aerosol particles, while eastern, southern, and southeastern (SE) wind directions are related to maximum loads of coarse aerosols (seasalt and particularly dust). These conclusions are strongly supported by Fig. $6 \mathrm{c}$ indicating maximum values of $\alpha_{440-870}$ (up to 1.5) for NW directions, and minimum values down to 0.8 for SE winds. Furthermore, our analysis has shown that only $1 \%$ of the total number of days with coarse aerosols are characterised by easterly wind directions, the majority being related to southern and SE directions, presumably indicating 


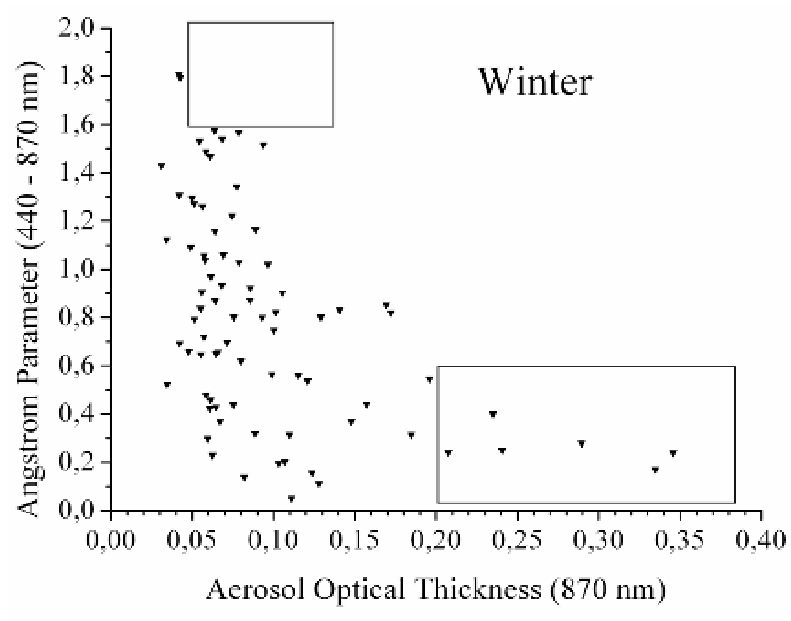

(a)

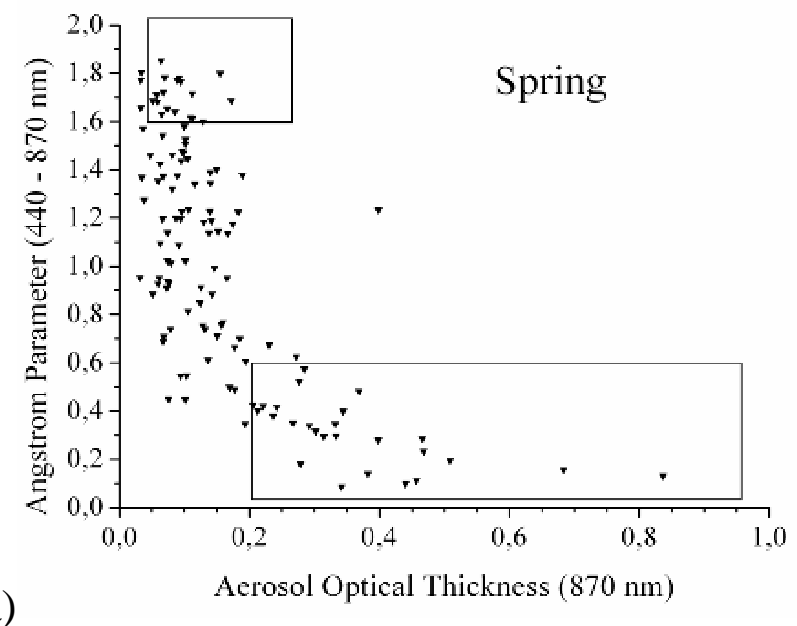

(b)
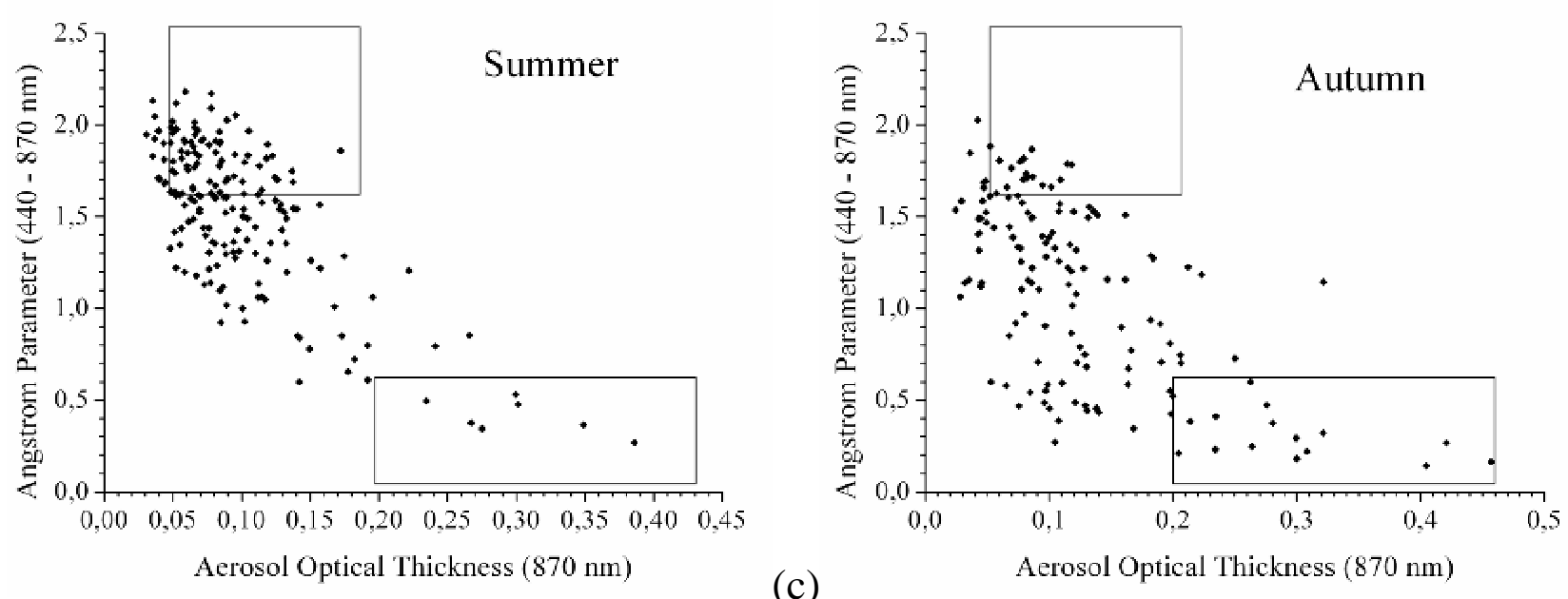

(c)

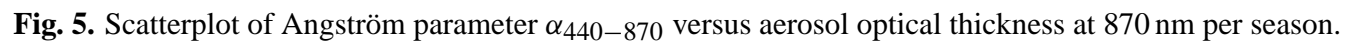

dust transport from North Africa. Indeed, this was verified by back-trajectory analyses for the relevant days, which have shown air-masses originating from Africa. Nevertheless, it should be noted that care must be taken in attempting to analyse wind measurements in combination with backtrajectories; wind measurements are instantaneous at the surface layer, while back-trajectories go back to a few days and are obtained at different levels in the atmosphere.

\subsection{Aerosol size distribution}

Figure 7 shows the average aerosol columnar ${ }^{1}$ volume size distribution $^{2}$ per season at the FORTH-AERONET monitoring site, derived from sky radiances. The distributions were averaged from daily distributions for each season, for the period 2003-2004. The AERONET daily aerosol volume size distributions are retrieved using the inversion procedure proposed by Dubovik and King (2000). The

${ }^{1}$ Note that henceforth (based on AERONET retrievals) V refers to the integrated volume of aerosols over the whole atmospheric column.

$2 \frac{d V}{d \ln r}=\frac{V}{\sqrt{2} \pi \cdot \ln \sigma} \exp \left[-\frac{1}{2}\left(\frac{\ln \left(r / r_{v}\right)}{\ln \sigma}\right)^{2}\right]$, where $\mathrm{dV} / \mathrm{d} \ln r$ is the aerosol volume size distribution, $\mathrm{V}$ is the total volume of particles, $\mathrm{r}$ is the particle radius, $\mathrm{r}_{v}$ is the volume geometric mean radius and $\sigma$ is the geometric standard deviation. 

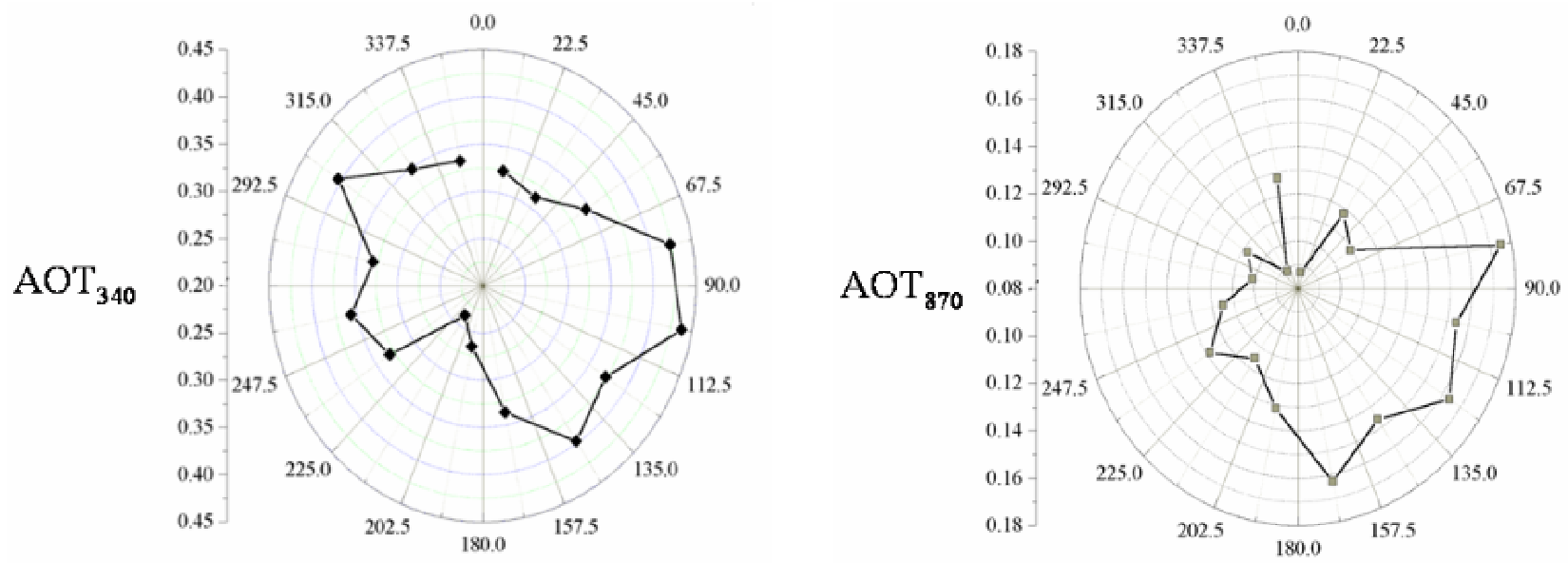

(a)

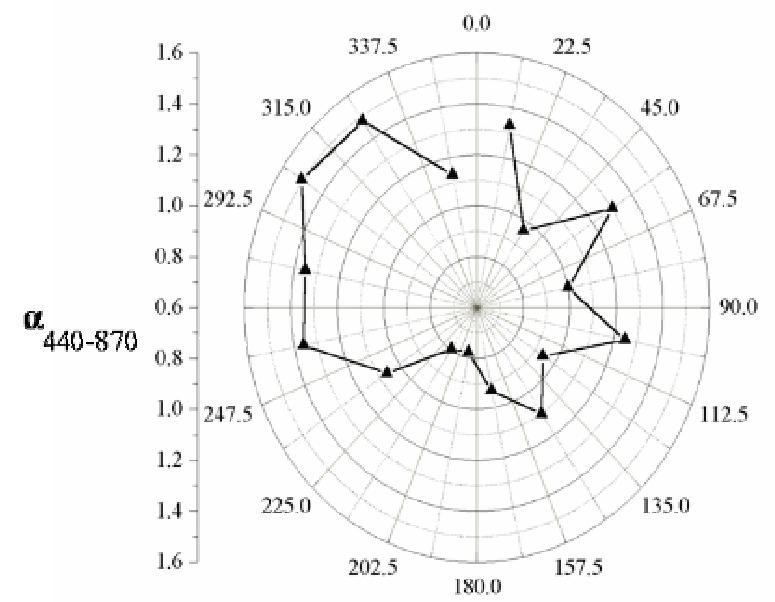

(c)

Fig. 6. Rose diagram of daily mean (a) aerosol optical thickness at $340 \mathrm{~nm}\left(\mathrm{AOT}_{340}\right)$, (b) at $870 \mathrm{~nm}\left(\mathrm{AOT}_{870}\right)$, and (c) of $\mathrm{Angström}$ parameter, $\alpha_{440-870}$, as function of wind direction at the FORTH-AERONET station in Crete.

FORTH-AERONET site shows bimodal aerosol volume size distributions with two distinct modes: a fine mode of principally anthropogenic origin, with radius between 0.05 and $0.5 \mu \mathrm{m}$, and a coarse mode of larger particles of natural origin, with radius ranging from 0.5 up to $15 \mu \mathrm{m}$. It is clear that both fine and coarse particles exist over Crete over all seasons, with sizes that do not change drastically from one season to another. However, the ratio between the two modes changes drastically, indicating variations in the relative contribution of different particles that constitute the total aerosol column. Thus, in winter and spring, the fine-mode peak is at $0.11 \mu \mathrm{m}$, and shifts towards $0.15 \mu \mathrm{m}$ in summer and autumn. In the coarse mode, the major part of aerosol volume is contributed by particles with radius from 1.0 to $5.0 \mu \mathrm{m}$. It is worth noting that in the coarse mode, two pseudo-modes can be distinguished, centered around 1.7 and $3.9 \mu \mathrm{m}$; these two pseudo-modes are attributed to desert dust and sea-salt maritime aerosols, as also suggested by Chiapello et al. (1999) and Tanré et al. (2001) for other AERONET sites. These two pseudo-modes are more distinct in spring, autumn and winter, in contrast to summer. Note that during winter the mode that peaks at $1.7 \mu \mathrm{m}$ becomes dominant, whereas in summer the dominant mode peaks at $3.9 \mu \mathrm{m}$. Our bimodal structure of aerosol volume size distribution (Fig. 7) is in agreement with the results of Kouvarakis et al. (2002) and Bardouki et al. (2003) derived from experimental campaigns conducted in Crete in May 1999, July 2000 and January 2001. Their analysis of the chemical and physical aerosol properties revealed a bimodal size distribution both in summer and winter, with peaks of both anions and cations at $0.13 \mu \mathrm{m}$ for 
the accumulation mode, and at $2.20 \mu \mathrm{m}$ for the coarse mode. The analysed size distributions of different individual chemical species suggested that anthropogenic compounds such as non-sea-salt sulfate (nss- $\mathrm{SO}_{4}^{2-}$ ), and biogenic-origin species such as $\mathrm{NH}_{4}^{+}$and MSA have their maximum in the fine mode (at about $0.13 \mu \mathrm{m}$, in terms of radius). On the other hand, anthropogenic nitrate $\left(\mathrm{NO}_{3}^{-}\right)$, sea-salt $\left(\mathrm{Na}^{+}\right)$and dust particles (nss- $\mathrm{Ca}^{2+}$ ) exhibit their maximum in the coarse mode (within the range $1.7-3.4 \mu \mathrm{m}$, in terms of radius, depending on the species). Note that the results of Kouvarakis et al. (2002) from the PAUR II (Photochemical Activity and Solar Ultraviolet Radiation) project suggest the peak radius of sea-salt and dust particles in May to be similar, while the results of Bardouki et al. (2003), from an experimental campaign in July 2000, show the peak of dust particles to be shifted to slightly larger radius compared to that for sea-salt particles. According to these findings, our coarse pseudomode centered around $3.9 \mu \mathrm{m}$ should be attributed to dust aerosols, while that at $1.7 \mu \mathrm{m}$ to maritime aerosols. Based on this, during summer the volume of dust particles dominates that of maritime aerosols, while in winter the situation is reversed. It is very interesting to see that over all seasons, the coarse-mode aerosol populations over Crete consist of both dust and maritime aerosols, with an almost equal contribution. The results of our study are in line with the results from the experimental campaigns in summer and winter, but provide additional insights for the other seasons.

The bimodal structure of aerosol spectra in Crete is in agreement with the results of Smirnov et al. (2002, 2003) who studied the optical and physical properties of maritime aerosols in five key island locations of the AERONET network in tropical and subtropical Pacific and Atlantic oceans over 2-5 years. They found that in the presence of pure maritime or mixed with dust, smoke or urban/industrial aerosols, the atmospheric column aerosol is characterised by a bimodal lognormal size distribution with a fine mode at effective radius, $\mathrm{R}_{\mathrm{eff}}{ }^{3}$, at $\sim 0.11-0.14 \mu \mathrm{m}$, and a coarse mode at $R_{\text {eff }} \sim 1.9-2.3 \mu \mathrm{m}$, in agreement with our results. Nevertheless, the aerosol size distributions in Crete are different to those in Pacific and Atlantic oceans in terms of the second coarse pseudo-mode at $3.9 \mu \mathrm{m}$. This is associated with a strong contribution of dust in Crete, originating from desert areas in North Africa. Note that bimodal aerosol size distributions in maritime environments are common and it has been suggested that their coarse mode arises from efficient processing by numerous consecutive cloud cycles (Hoppel et al., 1990; Pruppacher and Klett, 1997). There is another difference between the FORTH-Crete size distribution and

\footnotetext{
${ }^{3}$ The effective radius is defined and computed as: $\int^{r_{\max }} r^{3} \frac{d V}{d \ln r} d \ln r$

$R_{\mathrm{eff}}=\frac{r_{\min } r^{3} \frac{d V}{d \ln r} d \ln r}{r_{\min }^{\max } r^{2} \frac{d V}{d \ln r} d \ln r}$, where $\mathrm{r}_{\min }$ is the minimum and $\mathrm{r}_{\max }$ the maximum radius of the aerosol spectra
}

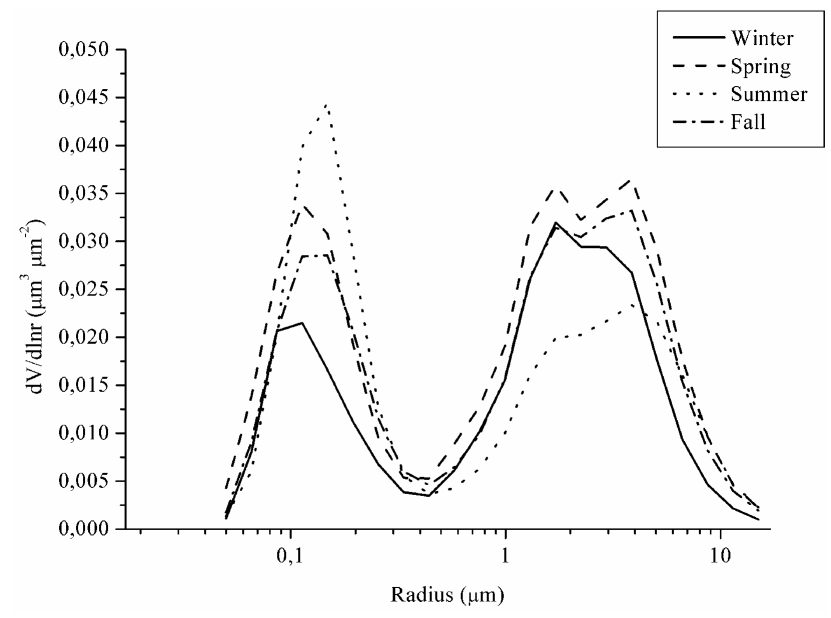

Fig. 7. Seasonal variation of aerosol columnar volume size distribution at the FORTH-AERONET station in Crete.

those over the Atlantic and Pacific Oceans. In Crete fine and coarse modes contribute equally, while at the oceanic sites, especially for the Pacific Ocean, the coarse mode is more significant than the fine one. This can be attributed to the less efficient cloud processing of aerosols over Crete than over remote oceanic areas due to the proximity of continental areas surrounding the Mediterranean.

Table 1 presents computed parameters of the bimodal lognormal aerosol volume size distribution in Crete, shown in Fig. 7 , such as the effective radius $\left(\mathrm{R}_{\mathrm{eff}}\right)$ and the columnar volume of particles per unit cross-section of atmospheric column $\left(\mathrm{C}_{v}{ }^{4}\right)$ for each mode. It should be noted that the number (343) of retrieved daily mean aerosol volume size distributions, and hence of associated parameters, is quite lower than the number of retrieved AOT and $\alpha_{440-870}$ (533), though still meaningful. The effective radius for fine mode varies around 0.13 throughout the year, while that for the coarse mode varies within the range 2.00-2.32. It should be noted that $\mathrm{R}_{\mathrm{eff}}$ of the coarse mode is slightly larger in summer than in the other seasons; this could arise from the larger relative contribution of the second (dust) pseudo-mode with respect to other seasons (see Fig. 7), due to the absence of wet removal processes of dust. The columnar volume concentration of aerosols, $\mathrm{C}_{v}$, ranges from 0.025 to 0.048 for the fine mode and from 0.046 to 0.075 for the coarse mode. The modal volume of coarse particles in Crete dominates that of the fine mode, except for summer when they are the same. Additionally, note that the maximum columnar volume of fine mode aerosols occur in summer, owing to the significant contribution of anthropogenic and natural fine pollution particles (see Sects. 3.1 and 3.2). The coarse mode has maximum columnar volume in spring and secondarily in autumn, i.e. when there is strong transport of dust. During

\footnotetext{
${ }^{4} \mathrm{C}_{v}$ was computed as: $C_{v}=\int_{r_{\min }}^{r_{\max }} \frac{d V}{d \ln r} d \ln r$
} 
Table 1. Seasonal averages of aerosol volume size distribution parameters at the FORTH-AERONET station in Crete; $\mathrm{R}_{\text {eff }}$ is the effective radius (in $\mu \mathrm{m}$ ) and $\mathrm{C}_{v}$ is the columnar volume of particles per unit cross section of atmospheric column $\left(\mu \mathrm{m}^{3} / \mu \mathrm{m}^{2}\right)$.

\begin{tabular}{llllll}
\hline & \multicolumn{2}{c}{ Fine mode } & \multicolumn{2}{c}{ Coarse mode } & Fine + Coarse \\
& $\mathrm{R}_{\mathrm{eff}}(\mu \mathrm{m})$ & $\mathrm{C}_{v}\left(\mu \mathrm{m}^{3} / \mu \mathrm{m}^{2}\right)$ & $\mathrm{R}_{\mathrm{eff}}(\mu \mathrm{m})$ & $\mathrm{C}_{v}\left(\mu \mathrm{m}^{3} / \mu \mathrm{m}^{2}\right)$ & $\mathrm{C}_{v}\left(\mu \mathrm{m}^{3} / \mu \mathrm{m}^{2}\right)$ \\
\hline Winter & 0.131 & 0.025 & 2.004 & 0.057 & 0.082 \\
Spring & 0.128 & 0.042 & 2.026 & 0.075 & 0.117 \\
Summer & 0.132 & 0.048 & 2.322 & 0.046 & 0.094 \\
Autumn & 0.135 & 0.037 & 2.141 & 0.066 & 0.103 \\
Year & 0.132 & 0.038 & 2.123 & 0.061 & 0.099 \\
\hline
\end{tabular}

these seasons, the $\mathrm{C}_{v}$ of the coarse mode is larger than that of the fine mode by up to 1.8 times (Table 1). Such a dominance of coarse aerosol volume has also been reported by Smirvov et al. (2002) for Atlantic and Pacific AERONET sites. The very large coarse-to-fine ratio of columnar volume concentration in winter (2.3) can be attributed to strong processing of aerosols by winter clouds, leading to broadening of aerosol spectra towards larger sizes and also to the presence of mineral dust and maritime particles, as suggested by back-trajectory analyses. Nevertheless, note that only 12 cases were available for analysis from FORTH-AERONET during this season. The maximum total $\mathrm{C}_{v}$ in Crete occurs in spring $\left(0.117 \mu \mathrm{m}^{3} / \mu \mathrm{m}^{2}\right.$, Table 1$)$, while the minimum $\left(0.082 \mu \mathrm{m}^{3} / \mu \mathrm{m}^{2}\right)$ occurs in winter.

\section{Summary and conclusions}

In this paper we have characterised the aerosol physical and optical properties over the eastern Mediterranean basin using a complete series of two-year (2003-2004) measurements from the recently established FORTH-AERONET station in Crete. This has been achieved by examining aerosol spectral optical thickness (AOT), Angström parameter $\alpha_{440-870}$, and properties of aerosol spectra such as volume size distribution and effective radius.

The amount and properties of aerosols in the eastern Mediterranean island of Crete were found to be strongly determined by the marine environment involving low concentrations of sea-salt aerosols produced by sea-spray, which constitute the background conditions. The AOT and $\alpha_{440-870}$ values are also influenced by the prevailing synoptic conditions implying transport of dust aerosols mainly from African deserts, and secondarily from the Middle-East and Anatolian plateau, and transport of pollution fine aerosols from central and eastern Europe, Turkey and western Europe.

The aerosol loads are relatively small over Crete compared to other AERONET continental sites around the Mediterranean Basin, as indicated by AOT values equal to $0.21 \pm 0.11$ at $500 \mathrm{~nm}$, but larger than aerosol loads in remote oceanic areas. In comparison with the rest of AERONET sites in the eastern Mediterranean Basin, there are differences in aerosol amount and seasonality. Aerosol optical thickness varies seasonally, especially in the UV and visible wavelengths, with maximum values in spring (March-May) and minimum values in winter, whereas large values are also observed in late summer and autumn (August and October). The large AOT values in spring and autumn are accompanied by corresponding Angström parameter values less than 0.5 , indicating the presence of coarse aerosols (dust and maritime). The relatively large AOT values during summer, associated with large values of $\alpha_{440-870}(>1.6)$ indicate the presence of fine aerosols. However, there is a large number of days with $0.5<\alpha_{440-870}<2.0$ corresponding to mixtures of fine and coarse particles that coexist within the atmospheric column. A large variety of aerosol types have been identified over Crete together with a large variability in aerosol content and size. In addition, a strong temporal variability in AOT and the Angström parameter $\left(\alpha_{440-870}\right)$ was found. These findings resulted from broad frequency distributions in

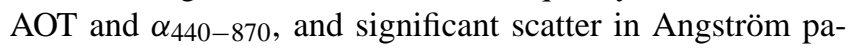
rameter versus $\mathrm{AOT}_{870}$ values (AOT varies within the range $0.02-1.17$, whereas $\alpha_{440-870}$ ranges from 0.05 up to 2.2). The measurements of aerosol optical properties were supplemented by back-trajectory analyses identifying the source areas and pathways of air masses carrying aerosols to Crete. Our results, indicate that during spring, but also in autumn, the large AOT and small $\alpha_{440-870}$ values are due to dust particles which are frequently transported mainly from North Africa and much less from Middle East. The trajectories were found to be quite long, and sometimes complicated, involving also close pollution sources such as Athens. During summer, large $\alpha_{440-870}$ values $(>1.6)$ indicate continental urban/industrial and biomass burning aerosols. These fine particles of anthropogenic origin are transported from western Europe, Balkans, former Soviet Union countries near the Black Sea, and Turkey, but also near pollution sources like the city of Athens, and they are accumulated in the atmosphere of Crete due to stagnant meteorological conditions and the absence of wet removal processes.

The above conclusions were further supported by correlations between wind direction measurements, and AOT and $\alpha_{440-870}$ data. Maximum aerosol loads and $\alpha_{440-870}$ values 
identified for NW winds are associated with fine aerosol particles, while maximum AOT and small $\alpha_{440-870}$ values for easterly, southeasterly, and southerly winds are related to coarse (basically dust) particles.

The volume size distribution of aerosols is bimodal, typical of maritime environments, and indicates the presence of both fine and coarse aerosols over Crete. The fine mode peaks at $0.11-0.15 \mu \mathrm{m}$ depending on the season, with an effective radius of about $0.13 \mu \mathrm{m}$, while the columnar volume of aerosols, $C_{v}$, ranges from 0.025 in winter to 0.048 in summer. The coarse mode has two pseudo-modes centered at 1.7 and $3.9 \mu \mathrm{m}$. The first mode (at $1.7 \mu \mathrm{m}$ ) is attributed to maritime aerosols and the second mode (at $3.9 \mu \mathrm{m}$ ) to dust aerosols. Certainly, more detailed analyses are required to draw definite conclusions about particle concentrations, since the total volume of an aerosol population involves the number density and the size of particles. The first pseudomode becomes dominant in winter, in contrast to summer, when the dominant mode peaks at $3.9 \mu \mathrm{m}$, whereas in the transient seasons the two pseudo-modes are about equal. Coarse aerosols dominate the total columnar volume of particles during all seasons except for summer, when they are of equal importance to fine particles.

The installation of the FORTH AERONET station in Crete was decided because of the interesting and complex location of this island in the center of the eastern Mediterranean Basin, surrounded by continental areas producing different aerosol types (e.g. desert dust, fine anthropogenic particles). The signature of these particles, together with that of background maritime aerosols, has been demonstrated by the present study. This is a significant difference to the rest of AERONET stations installed in the eastern Mediterranean Basin (Erdemli, Nes Ziona, Sede Boker) mainly on coastal or near-to-coast locations and closer to continental aerosol sources. The results of this study show that the FORTH AERONET station in Crete is well located for capturing dust transport events from North Africa. The climatic effect of aerosols, based on the measured aerosol properties at the FORTH site, will be the subject of a future study where the aerosol induced changes to the surface and atmospheric radiation budgets will be addressed in detail using state of the art radiative transfer models.

Acknowledgements. The project (Code 1964) is co-funded by the European Social Fund \& National Resources-EPEAEK IIPythagoras.

Edited by: R. Volkamer

\section{References}

Alpert, P. and Ziv, B.: The Sharav Cyclone: Observations and some theoretical considerations, J. Geophys. Res., 94, 18 495-18 514, 1989.

Andreae, T. W., Andreae, M. O., Ichoku, C., Maenhaut, W., Cafmeyer, J., Karnieli, A., and Orlovsky, L.: Light scattering by dust and anthropogenic aerosol at a remote site in the Negev desert, Israel, J. Geophys. Res., 107(D2), 4008, doi:10.1029/2001JD900252, 2002.

Balis, D. S., Amiridis, V., Zerefos, C., Gerasopoulos, E., Andreae, M., Zanis, P., Kazantzidis, A., Kazadzis, S., and Papayannis, A.: Raman lidar and sunphotometric measurements of aerosol optical properties over Thessaloniki, Greece during a biomass burning episode, Atmos. Environ., 37, 4529-4538, 2003.

Balis, D. S., Amiridis, V., Zerefos, C., Kazantzidis, A., Kazadzis, S., Bais, A. F., Meleti, C., Gerasopoulos, E., Papayannis, A., Matthias, V., Dier, H., and Andreae, M. O.: Study of the effect of different type of aerosols on UV-B radiation from measurements during EARLINET, Atmos. Chem. Phys., 4, 307-321, 2004a.

Balis, D. S., Amiridis, V., Nickovic, S., Papayannis, A., and Zerefos, C.: Optical properties of Saharan dust layers as detected by a Raman lidar at Thessaloniki, Greece, Geophys. Res. Lett., 31, 13104, doi:10.1029/2004GL019881, 2004b.

Bardouki, H., Liakakou, H., Economou, C., Sciare, J., Smolik, J., Zdimal, V., Eleftheriadis, K., Lazaridis, M., Dye, C., and Mihalopoulos, N.: Chemical composition of size-resolved atmospheric aerosols in the eastern Mediterranean during summer and winter, Atmos. Environ., 37, 195-208, 2003.

Barkan, J., Alpert, P., Kutiel, H., and Kishcha, P.: Synoptics of dust transportation days from Africa toward Italy and central Europe, J. Geophys. Res., 110, D07208, doi:10.1029/2004JD005222, 2005.

Bartzokas, A., Lolis, C. J., and Metaxas, D. A.: A study on the intra-annual variation and the spatial distribution of precipitation amount and duration over Greece on a 10-day basis, Int. J. Climatol., 23, 207-222, 2003.

Chiapello, I., Prospero, J. M., Herman, J. R., and Hsu, N. C.: Detection of mineral dust over the North Atlantic Ocean and Africa, J. Geophys. Res., 104, 9277-9291, 1999.

Chen, Y. and Penner, J. E.: Uncertainty analysis for estimates of the first indirect aerosol effect, Atmos. Chem. Phys., 5, 2935-2948, 2005 , http://www.atmos-chem-phys.net/5/2935/2005/.

Dayan, U., Heffter, J., Miller, J., and Gutman, G.: Dust intrusion events into the Mediterranean basin, J. Appl. Meteorol., 30, 1185-1199, 1991.

Dubovik, O., Yokota, T., and Sasano, Y.: Improved technique for data inversion and its application to the retrieval algorithm for ADEOS/ILAS, Adv. Space Res., 21, 397-403, 1998.

Dubovik, O., Smirnov, A., Holben, B. N., King, M. D., Kaufman, Y. J., Eck, T. F., and Slutker, I.: Accurancy assessments of aerosol optical properties retrieved from Aerosol Robotic Network (AERONET) Sun and sky radiance measurements, J. Geophys. Res., 105, 9791-9806, 2000.

Dubovik, O. and King, M. D.: A flexible inversion algorithm for retrieval of aerosol optical properties from Sun and sky radiance measurements, J. Geophys. Res., 105, 20 673-20 696, 2000.

Dubovik, O., Holben, B. N., Eck, T. F., Smirnov, A., Kaufman, Y. J., King, M. D., Tanré, D., and Slutker, I.: Variability of ab- 
sorption and optical properties of key aerosol types observed in worldwide locations, J. Atmos. Sci., 59, 590-608, 2002a.

Dubovik, O., Holben, B. N., Lapyonok, T., Sinyuk, A., Mishchenko, M. I., Yang, P., and Slutker, I.: Non-spherical aerosol retrieval method employing light scattering by spheroids, Geophys. Res. Lett., 29(10), 1415, doi:10.1029/2001GL014506, 2002b.

Eisinger, M. and Burrows, J. P.: Tropospheric Sulfur Dioxide observed by the ERS-2 GOME Instrument, Geophys. Res. Lett., 25, 4177-4180, 1998.

Formenti, P., Andreae, M. O., Andreae, T. W., Ichoku, C., Schebeske, G., Kettle, J., Maenhaut, W., Cafmeyer, J., Ptasinsky, J., Karnieli, A., and Lelieveld, J.: Physical and chemical characteristics of aerosols over the Negev Desert (Israel) during summer 1996, J. Geophys. Res., 106, 4871-4890, 2001a.

Formenti, P., Andreae, M. O., Andreae, T. W., Galani, E., Vasaras, A., Zerefos, C., Amiridis, V., Orlovsky, L., Karnieli, A., Wendisch, M., Wex, H., Holben, B. N., Maenhaut, W., and Lelieveld, J.: Aerosol optical properties and large scale transport of air masses: Observations at a coastal and a semiarid site in the eastern Mediterranean during summer 1998, J. Geophys. Res., 106, 9807-9826, 2001b.

Formenti, P., Reiner, O., Sprung, D., Andreae, M. O., Wendisch, M., Wex, H., Kindred, D., Dewey, K., Kent, J., Tzortziou, M., Vasaras, A., and Zerefos, C.: The STAAARTE-MED 1998 summer airborne measurements over the Aegean Sea: 1. Aerosol particles and trace gases, J. Geophys. Res., 107, 4450, doi:10.1029/2001JD001337, 2002a.

Formenti, P., Boucher, O., Reiner, T., Sprung, D., Andreae, M. O., Wendisch, M., Wex, H., Kindred, D., Tzortziou, M., Vasaras, A., and Zerefos, C.: The STAAARTE-MED 1998 summer airborne measurements over the Aegean Sea: 2. Aerosol scattering and absorption, and radiative calculations, J. Geophys. Res., 107, 4451, doi:10.1029/2001JD001536, 2002b.

Gerasopoulos, E., Andreae, M. O., Zerefos, C. S., Andreae, T. W., Balis, D., Formenti, P., Merlet, P., Amiridis, V., and Papastefanou, C.: Climatological aspects of aerosol optical properties in Northern Greece, Atmos. Chem. Phys., 3, 2025-2041, 2003, http://www.atmos-chem-phys.net/3/2025/2003/.

Gerasopoulos, E., Kouvarakis, G., Vrekoussis, M., Kanakidou, M., and Mihalopoulos, N.: Ozone variability in the marine boundary layer of the Eastern Mediterranean based on 7-year observations, J. Geophys. Res., 110, D15309, doi:10.1029/2005 JD005991, 2005.

Gerasopoulos, E., Kouvarakis, G., Babasakalis, P., Vrekoussis, M., Putaud, J. P., and Mihalopoulos, N.: Origin and variability of particulate matter $\left(\mathrm{PM}_{10}\right)$ mass concentrations over the Eastern Mediterranean, Atmos. Environ., 40, 4679-4690, 2006.

Hatzianastassiou, N., Katsoulis, B., and Vardavas, I.: Global distribution of aerosol direct radiative forcing in the ultraviolet and visible arising under clear skies, Tellus, 56B, 51-71, 2004.

Haywood, J. and Boucher, O.: Estimates of the direct and indirect radiative forcing due to tropospheric aerosols: A review, Rev. Geophys., 38, 513-543, 2000.

Holben, B. N., Eck, T. F., Slutsker, J., et al.: AERONET - A federated instrument network and data archive for aerosol characterization, Rem. Sens. Environ. 66, 1-16, 1998.

Holben, B. N., Tanré, D., Smirnov, A., Eck, T. F., Slutsker, I., Abuhassan, N., Newcomb, W. W., Schafer, J., Chatenet, B., Lav- enue, F., Kaufman, Y. J., Vande Castle, J., Setzer, A., Markham, B., Clark, D., Frouin, R., Halthore, R., Karnieli, A., O’Neill, N. T., Pietras, C., Pinker, R. T., Voss, K., and Zibordi, G.: An emerging ground-based aerosol climatology: Aerosol Optical Depth from AERONET, J. Geophys. Res., 106, 12 067-12 097, 2001.

Hoppel, W. A., Fitzgerald, J. W., Frick, G. M., Larson, R. E., and Mack, E. J.: Aerosol size distributions and optical-properties found in the marine boundary-layer over the Atlantic-ocean, J. Geophys. Res., 95, 3659-3686, 1990.

Ichoku, C., Andreae, M. O., Andreae, T. W., Meixner, F. X., Schebeske, G., Formenti, P., Maenhaut,W., Cafmeyer, J., Ptasinski, J., Karnieli, A., and Orlovsky, L.: Interrelationships between aerosol characteristics and light scattering during late-winter in an Eastern Mediterranean arid environment, J. Geophys. Res., 104, 24 371-24 393, 1999.

Intergovernmental Panel on Climate Change (IPCC) Climate change 2001: The Scientific Basis, edited by: Houghton, J. T., Ding, Y., Griggs, D. J., et al., Contribution of Working Group I to the Third Assessment Report of the Intergovernmental Panel on Climate Change, 881pp., Cambridge University Press, New York, 2001.

Israelevich, P. L., Ganor, E., Levin, Z. Z., and Joseph, J. H.: Annual variations of physical properties of desert dust over Israel, J. Geophys. Res., 108(D13), 4381, doi:10.1029/2002JD003163, 2003.

Israelevich, P. L., Levin, Z., Joseph, J. H., and Ganor, E.: Desert aerosol transport in the Mediterranean region as inferred from TOMS aerosol index, J. Geophys. Res., 107, 4572, doi:10.1029/2001JD002011, 2002.

Jaenicke, R.: Tropospheric aerosols, in: Aerosol-Cloud-Climate Interactions, edited by: Hobbs, P., Academic, San Diego, CA, 131, 1993.

Kalivitis, N., Gerasopoulos, E., Vrekoussis, M., Kouvarakis, G., Kubilay, N., Hatzianastassiou, N., Vardavas, I., and Mihalopoulos, N.: Dust transport over the eastern Mediterranean derived from TOMS, AERONET and surface measurements, J. Geophys. Res., in press, doi:10.1029/2006JD007510, 2006.

Karyampudi, V. M., Palm, S. P., Reagen, J. A., et al.: Validation of the Sahara dust plume conceptual model using lidar, Meteosat and ECMWF, Bull. Am. Meteorol. Soc., 80, 1045-1075, 1999.

Katsoulis, B. D., Makrogiannis, T. J., Goutsidou, Y. A.: Monthly anticyclonicity in southern Europe and the Mediterranean region, Theor Appl Climatol., 59, 51-59, 1998.

Kaufman, Y. J., Dubovik, O., Smirnov, A., and Holben, B. N.: Remote sensing of non-aerosol absorption in cloud free atmosphere, Geophys. Res. Lett., 29(18), 1857, doi:10.1029/2001GL014399, 2002.

Kouvarakis, G., Doukelis, Y., Mihalopoulos, N., Rapsomanikis, S., Sciare, J., and Blumtharel, M.: Chemical, physical and optical characterization of aerosols during PAUR II experiment, J. Geophys. Res., 107(18), 8141, doi:10.1029/2000JD000291, 2002.

Kubilay, N. and Saydam, A. C.: Trace elements in atmospheric particulates over the eastern Mediterranean: Concentrations, sources, and temporal variability, Atmos. Environ., 29, 22892300, 1995.

Kubilay, N., Cokacar, T., and Oguz, T.: Optical properties of mineral dust outbreaks over the northeastern Mediterranean, J. Geophys. Res., 108(D21), 4666, doi:10.1029/2003JD003798, 2003.

Lelieveld, J., Berresheim, H., Borrmann, S., et al.: Global air pollu- 
tion crossroads over the Mediterranean, Science, 298, 794-799, 2002.

Lohmann, U. and Feichter, J.: Global indirect aerosol effects: a review, Atmos. Chem. Phys., 5, 715-737, 2005, http://www.atmos-chem-phys.net/5/715/2005/.

Luria, M., Peleg, M., Sharf, G., Tov-Alper, D. S., Spitz, N., Ben Ami, Y., Gawii, Z., Lifschitz, B., Yitzchaki, A., and Seter, I.: Atmospheric sulfur over the east Mediterranean region, J. Geophys. Res, 101, 25 917-25 930, 1996.

Luterbacher J., Dietrich, D., Xoplaki, E., Grosjean, M., and Wanner, H.: European seasonal and annual temperature variability, trends, and extremes since 1500, Science, 303, 1499-1503, 2004.

Marticorena, B. and Bergametti, G.: Two-year simulations of seasonal and interannual changes of the Saharan dust emissions, Geophys. Res. Lett., 23(15), 1921-1924, 1996.

Metaxas, D. A. and Bartzokas, A.: Pressure Covariability over the Atlantic, Europe and N. Africa - Application: Centers of Action for Temperature, Winter Precipitation and Summer Winds in Athens, Greece, Theor. Appl. Climatol., 49, 9-18, 1994.

Mihalopoulos, N., Stephanou, E., Kanakidou, M., Pilitsidis, S., and Bousquet, P.: Tropospheric aerosol ionic composition in the eastern Mediterranean region, Tellus B, 49, 314-326, 1997.

Moulin, C., Lambert, C. E., Dayan, U., et al.: Satellite climatology of African dust transport in Mediterranean atmosphere, J. Geophys. Res., 103, 13 137-13 144, 1998.

Palutikof, J. P., Conte, M., Casimiro Mendes, J., Goodess, C. M., and Espirito Santo, F.: Climate and Climatic Change, in: Mediterranean desertification and land use, edited by: Brandt, C. J. and Thomas J. B., J. Wiley and Sons, p. 43-86, 1996.

Papayannis, A., Balis, D., Amiridis, V., Chourdakis, G., Tsaknakis, G., Zerefos, C., Castanho, A. D. A., Nickovic, S., Kazadzis, S., and Grabowski, J.: Measurements of Saharan dust aerosols over the Eastern Mediterranean using elastic backscatter-Raman lidar, spectrophotometric and satellite observations in the frame of the EARLINET project, Atmos. Chem. Phys., 5, 2065-2079, 2005, http://www.atmos-chem-phys.net/5/2065/2005/.

Paronis, D., Doulac, F., Chazette, P., Hamonou, E., and Liberti, G. L.: Aerosols optical thickness monitoring in the Mediterranean, J. Aerosol Sci., 30, 631-632, 1998.
Pinker, R. T., Ferrare, R. A., Karnieli, A., Aro, T. O., Kaufman, Y. J., and Zangvil, A.: Aerosol optical depths in a semiarid region, J. Geophys. Res., 102, 11 123-11 137, 1997.

Prospero, J. M., Ginoux, P., Torres, O., and Nicholson, S. E.: Environmental characterization of global sources of atmospheric soil dust derived from the Numbus 7 Total Ozone Mapping Specrometer (TOMS) absorbing aerosol product, Rev. Geophys., 40(1), 102, doi:10,1029/2000RG000095, 2002.

Pruppacher, H. R. and Klett, J. D.: Microphysics of Clouds and Precipitation, 2nd revised and enlarged edn with an introduction to cloud chemistry and cloud electricity, Kluwer, Dordrecht, 954 pp, 1997.

Sciare, J., Bardouki, H., Moulin, C., and Mihalopoulos, N.: Aerosol sources and their contribution to the chemical composition of aerosols in the Eastern Mediterranean Sea during summertime, Atmos. Chem. Phys., 3, 291-302, 2003, http://www.atmos-chem-phys.net/3/291/2003/.

Smirnov, A., Holben, B. N., Kaufman, Y. J., Dubovik, O., Eck, T. F., Slutsker, I., Pietras, C., Halthore, R. N.: Optical properties of atmospheric aerosol in maritime environments, J. Atmos. Sci., 59, 501-523, 2002.

Smirnov, A., Holben, B. N., Dubovik, O., Frouin, R., Eck, T. F., and Slutsker, I.: Maritime component in aerosol optical models derived from Aerosol Robotic Network data, J. Geophys. Res., 108(D1), 4033, doi:10.1029/2002JD002701, 2003.

Tanré, D., Kaufman, Y. J., Holben, B. N., Chatenet, B., Karnieli, A., Lavenu, F., Blarel, L., Dubovik, O., Remer, L. A., and Smirnov, A.: Climatology of dust aerosol size distribution and optical properties derived from remotely sensed data in the solar spectrum, J. Geophys. Res., 106(D16), 18 205-18218, doi:10.1029/2000JD900663, 2001.

Zerefos, C., Ganev, K., Kourtidis, K., Tzortziou, M., Vasaras, A., and Syrakov, E.: On the origin of SO2 above Northern Greece, Geophys. Res. Lett., 27, 365-368, 2000.

Zerefos, C. S., Kourtidis, K. A., Melas, D., et al.: Photochemical Activity and Solar Ultraviolet Radiation (PAUR) Modulation Factors: An overview of the project, J. Geophys. Res., 107, 8134, doi:10.1029/2000JD000134, 2002. 